\title{
AN ASSESSMENT OF THE INFLUENCE OF SELECTED HERBICIDES ON THE MICROBIAL PARAMETERS OF SOIL IN MAIZE (ZEA MAYS) CULTIVATION
}

\author{
NIEWIADOMSKA, A. ${ }^{1 *}$ - SULEWSKA, $\mathrm{H}^{2}{ }^{2}$ - WOLNA-MARUWKA, A. ${ }^{1}-$ WARACZEWSKA, Z. ${ }^{1}$ - \\ BUDKA, A. ${ }^{3}-$ RATAJCZAK, $^{2}{ }^{2}$ \\ ${ }^{1}$ Department of General and Environmental Microbiology, University of Life Sciences \\ Szydłowska 50, 60-656 Poznań, Poland \\ ${ }^{2}$ Department of Agronomy, University of Life Sciences \\ Dojazd 11, 60-632 Poznań, Poland \\ ${ }^{3}$ Department of Mathematical and Statistical Methods, University of Life Sciences \\ Wojska Polskiego 28, 60-637 Poznań, Poland \\ *Corresponding author \\ e-mail: alicja.niewiadomska@onet.eu \\ (Received $3^{\text {rd }}$ Apr 2018; accepted $13^{\text {th }}$ Jun 2018)
}

\begin{abstract}
Application of herbicides inhibit development of weeds, but at the same time they can negatively influence soil microbial activity. The microbiological indicators allow estimating changes in soil contaminated with herbicides. The aim of the study was to assess the influence of selected postemergence herbicides: Stellar 210 SL + Olbras, Maister Power 42.5 OD, Laudis 44 OD, Collage 064 OD, Hector Max 66.5 WG + Trend $0.1 \%$ and Arigo $51 \mathrm{WG}+$ Trend $0.1 \%$ on the microbial activity of soil under maize plantation. The research included assessment of the count of selected groups of microorganisms, the activity of soil enzymes and soil fertility (BIF), as well as soil sensitivity (RS) to the preparations tested in the experiments. The results of study show that in some cases the count of the groups of microorganisms under study increased (the total bacterial count, the count of copiotrophs), especially immediately after the herbicide treatment, i.e. at the first term of analyses. The study showed that sixty days after the herbicide treatment all the xenobiotics exhibited strongly negative influence on the dehydrogenase activity (DHA). The activity of alkaline phosphatase and catalase became significantly reduced thirty days after the soil treatment with all of the herbicides used in the experiment. The highest values of biological index of fertility (BIF) were noted thirty days after the herbicide treatment and were strictly correlated with DHA and PAC.
\end{abstract}

Keywords: post-emergence herbicides, total bacteria, fungi, dehydrogenase, phosphomonoesterases, BIF

\section{Introduction}

For many years chemical crop protection products have been commonly used in farming practice to achieve the highest possible yield and desirable quality of crops. Intensive agricultural production as well as large numbers of pests and weeds cause increased use of pesticides (Baćmaga, 2007a). Herbicides are a group of crop protection products. They are considerably diversified and provide highly effective protection of particular crops. Long-term use of herbicides results in their accumulation in soil and it may cause a wide range of side effects (Walker et al., 2001). At present there are new EU regulations concerning integrated crop protection methods (introduced in Poland in 2014), which prefer non-chemical to chemical crop protection. The same active substances cannot be used consecutively in order to reduce the negative effect of agriculture on the environment. 
Modern herbicides biodegrade rapidly and they are effective even at small doses or at divided doses. Nevertheless, whenever the active substance of the pesticide is applied, it may affect the population and species composition of soil microorganisms. It may also indirectly influence the biochemical processes in which these microorganisms take part (Baćmaga et al., 2013). When herbicides are applied, the microbial biomass of soil may increase, decrease or remain the same (Singh and Ghoshal, 2010). Both the active substance and its decomposition products may be more toxic than the input products. They also influence the population and bioactivity of microorganisms (Arias-Estévez et al., 2008).

The count of soil microorganisms and the soil enzymatic activity are the indicators which enable assessment of changes in soil pollution and fertility (Baćmaga et al., 2007b).

The aim of the study was to assess the influence of selected post-emergence herbicides: Stellar 210 SL + Olbras, Maister Power 42.5 OD, Laudis 44 OD, Collage 064 OD, Hector Max 66.5 WG + Trend $0.1 \%$ and Arigo $51 \mathrm{WG}+$ Trend $0.1 \%$ on the microbial activity of soil under maize plantation. The research included assessment of the count of selected groups of microorganisms (total bacteria, actinobacteria, moulds, oligotrophs and copiotrophs), the activity of soil enzymes (dehydrogenase, acid and alkaline phosphatase, catalases) and soil fertility (BIF), as well as soil sensitivity to the preparations tested in the experiments.

\section{Material and methods}

Between 2015 and 2016 experiments were conducted in the village of Swadzim $\left(52^{\circ} 26 \mathrm{~N}, 16^{\circ} 45 \mathrm{E}\right)$ in fields belonging to the Experimental and Educational Station Gorzyń, Poznań University of Life Sciences, Poland.

The experiments were conducted in plots on Haplic Luvisols (according to the FAO/WRB classification [IUSS Working Group WRB, 2007]), derived from loamy sands. (Table 1).

The soil texture was determined using sieving (sand fraction) for silt and clay fraction (Van Reeuwijk, 2002).

Table 1. The texture of soil material sampled from 0-25 depth

\begin{tabular}{c|c|c|c|c}
\hline \multicolumn{3}{c|}{ Percentage content of soil fractions \% } & \multirow{2}{*}{ Texture class } \\
\hline \multirow{3}{*}{ Fraction } & $\begin{array}{c}\text { sand } \\
2-0.05 \mathrm{~mm}\end{array}$ & $\begin{array}{c}\text { silt } \\
0.05-0.002 \mathrm{~mm}\end{array}$ & $\begin{array}{c}\text { clay } \\
<0.002 \mathrm{~mm}\end{array}$ & \\
\cline { 2 - 5 } & 78 & 18 & 4 & LS \\
\hline
\end{tabular}

LS - loamy sand

P9175 maize cultivar (FAO 280) was sown in plots of $28 \mathrm{~m}^{2}$, in four replications for each treatment. The cultivar is highly resistant to water deficit and high temperatures.

Soil samples were collected at three terms, which differed in the number of days following the application of individual herbicides. The samples were collected at the following terms:

$1^{\text {st }}$ term -3 days after herbicide treatment,

$2^{\text {nd }}$ term - 30 days after herbicide treatment,

$3^{\text {rd }}$ term - 60 days after herbicide treatment. 
Individual experimental samples were collected from seven variants, which differed in the type of herbicides applied. One variant did not receive any chemical protection and was used for reference (Table 2).

Table 2. The field experiment scheme

\begin{tabular}{|c|c|c|}
\hline Treatment & Activity substances of herbicide & Doses of herbicide \\
\hline 1. Control & without herbicide & without herbicide \\
\hline 2. Stellar $210 \mathrm{SL}+$ Olbras & Dicamba, topramezon + adjuvant & $1.25 \mathrm{l} / \mathrm{ha}+1 \mathrm{l} / \mathrm{ha}$ \\
\hline 3. Maister Power 42.5 OD & $\begin{array}{l}\text { Iodosulfuron-methyl-sodium, } \\
\text { foramsulfuron, methyl thiencarbazone }\end{array}$ & $1.25-1.5 \mathrm{l} / \mathrm{ha}$ \\
\hline 4. Laudis $44 \mathrm{OD}$ & Tembotrione & $2-2.5 \mathrm{l} / \mathrm{ha}$ \\
\hline 5. Collage 064 OD & Nicosulfuron, thifensulfuron-methyl & $1 \mathrm{l} / \mathrm{ha}$ \\
\hline 6. Hector Max 66.5 WG + Trend $0.1 \%$ & $\begin{array}{l}\text { Nicosulfuron, rimsulfuron, dicamba }+ \\
\text { adjuvant }\end{array}$ & $330-440 \mathrm{~g} / \mathrm{ha}$ \\
\hline 7. Arigo $51 \mathrm{WG}+$ Trend $0.1 \%$ & $\begin{array}{c}\text { Mesotrione, nicosulfuron, rimsulfuron + } \\
\text { adjuvant }\end{array}$ & $330 \mathrm{~g} / \mathrm{ha}$ \\
\hline
\end{tabular}

\section{Weather conditions}

It is generally accepted that climatic conditions found throughout Poland are suitable for maize cultivation. This species needs approx. $500 \mathrm{~mm}$ annual precipitation to grow. The weather conditions during the experiment were characterised with Sielianinov hydrothermal coefficient K (Skowera, 2004). Selyaninov hydrothermal coefficient K was calculated according to the formula $K=(P \cdot 10) /(T \cdot L)$, where $K$ Sielianinov hydrothermal coefficient, $\mathrm{P}$ - total monthly precipitation, $\mathrm{T}$ - average monthly temperature, L - number of days in the month (Fig. 1). In all the years mean air temperature ranged from 8.6 to $10^{\circ} \mathrm{C}$ and it was comparable to the multiannual mean. A crucial element of optimal growth and biomass yielding conditions is also total precipitation, particularly its distribution. Variability of weather conditions in the years of the study was reflected in the values of the Sielianinov coefficient. More advantageous moisture conditions for maize were found in the year 2016 than in the drier $2015(\mathrm{~K}=0.9)$.

Interpretation of the Sielianinov hydrothermal coefficient:

$\mathrm{K}>1.5$ - excessive moisture for all plants

$\mathrm{K}=1.0-1.5$ - sufficient moisture

$\mathrm{K}=0.5-1.0$ - insufficient moisture

$\mathrm{K}<0.5$ - moisture level below the requirement for most plants - drought.

\section{Soil enzymatic activity}

The analyses of the enzymatic activity of soil in different variants (each in four replication) were based on the colorimetric method applied to measure the dehydrogenase activity (EC 1.1.1. DHA), where 1\% TTC (triphenyl tetrazolium chloride) was used as a substrate. The measurement took place after a 24-hour 
incubation at a temperature of $30^{\circ} \mathrm{C}$ and a wavelength of $485 \mathrm{~nm}$ and it was expressed as $\mu$ mol TPF (triphenyl formazane) $24 \mathrm{~h}^{-1} \mathrm{~g}^{-1} \mathrm{dm}$ of soil (Thalmann, 1968).

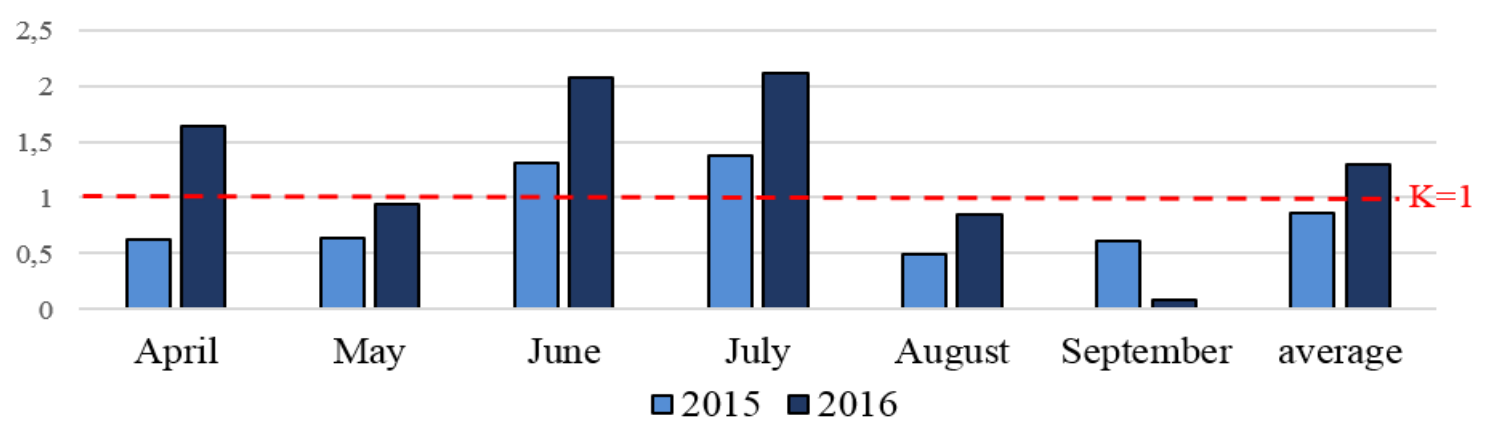

Figure 1. Humidity characteristic of the months of the vegetation period of 2015-2016 according to the value of the Sielianinov hydrothermal coefficient $(K)$

Apart from that, the acid and alkaline phosphomonoesterase (EC 3.1.3.2, PAC/PAL) activity were analysed with the method developed by Tabatabai and Bremner (1969). The activity was analysed using disodium p-nitrophenyl phosphate tetrahydrate as a substrate after $1 \mathrm{~h}$ incubation at a temperature of $37^{\circ} \mathrm{C}$ and wavelength of $400 \mathrm{~nm}$. The results were converted into $\mu \mathrm{mol}$ ( $\mathrm{p}$-nitrophenol) $\mathrm{PNP} \mathrm{h}^{-1} \mathrm{~g}^{-1} \mathrm{dm}$ of soil.

The catalyse activity (EC 1.11.1.6) was analysed manometrically with the method developed by Johnsons and Temple (1964), where $0.3 \% \mathrm{H}_{2} \mathrm{O}_{2}$ was used as a substrate. After a 20 minute incubation at room temperature $\left(20^{\circ} \mathrm{C}\right)$ it was titrated with $0.02 \mathrm{M}$ $\mathrm{KMnO}_{4}$ until its colour was light pink. The value was expressed as mmol $\mathrm{H}_{2} \mathrm{O}_{2} \mathrm{~g}^{-1}$ d.m. $\min ^{-1}$.

\section{Measurement of biological index of fertility (BIF)}

The biological index of fertility (BIF) was measured using the dehydrogenase activity (DHA) and catalyse activity (CAT) in the formula: (DHA +kCAT)/2, where $\mathrm{k}$ is the proportionality factor amounting to 0.01 (Saviozzi et al., 2004).

\section{Microbial analyses}

Soil samples were collected at a depth of 0-20 $\mathrm{cm}$ from interrows in the maize plantation. Volume of the samples to microbiological and biochemical tests was 700 $800 \mathrm{~g}$, which was sampled by using Egner's sticks from 10 points of each variant plot.

The serial dilution method developed by Koch was applied to measure the count of microorganisms on appropriate agar mediums (in five replicates). The average count of colonies per dry mass of soil was calculated:

- the total bacterial count was measured on ready Merck-Standard count agar after 5 days of incubation at $25^{\circ} \mathrm{C}$;

- moulds were measured on a Martin medium after 5 days of incubation at $24^{\circ} \mathrm{C}$;

- actinobacteria were measured on a Pochon medium after 5 days of incubation at $25^{\circ} \mathrm{C}$;

- copiotrophs were measured on an NB (Nutrient Broth) medium (Ohta and Hattori, 1980) after 5 days of incubation at $25^{\circ} \mathrm{C}$; 
- oligotrophs were measured on a DNB (Dilution Nutrient Broth) medium (Ohta and Hattori, 1980) after 5 days of incubation at $25^{\circ} \mathrm{C}$.

The formula (Eq. 1) proposed by Orwin and Wardle (2004) was used to estimate soil resistance (RS) to contamination with the herbicides under analysis:

$$
\mathrm{RS}=1-\frac{2\left|\mathrm{D}_{0}\right|}{\mathrm{C}_{0}+\left|\mathrm{D}_{0}\right|}
$$

where:

$C_{0}$ - soil resistance under natural conditions over time $\mathrm{t}_{0}$,

$P_{0}-$ resistance of soil subjected to pressure over time, $D_{0}=\mathrm{C}_{0}-\mathrm{P}_{0}$.

\section{Statistical analysis}

Two-way analysis of variance $(\alpha=0.05)$ was used to compare the mean values of biological parameters at individual terms of analyses and the influence of selected herbicide combinations. Next, post-hoc Tukey HSD test was applied. Principal Component Analysis (PCA) was used to analyse the bioactivity date at individual maize development phases in consequence of herbicide treatment.

\section{Results}

\section{Microbial number}

The results of microbial analyses are mean values of the two years of the research. Our results in general were consistent in the years of study so we decided to make a synthesis from years. The two-way analysis of variance showed that the factors under study significantly influenced the total bacterial count as well as the count of actinobacteria, copiotrophs and oligotrophs. There was no significant dependence between the factors and the count of moulds (Table 3).

Table 3. F test statistics and significance levels of two-way analysis of variance for the number of selected groups of microorganisms associated with herbicides and terms research fixed factors $(* * * p=0.001$. ** $p=0.01 . * p=0.05 . n s-$ not statistically significant)

\begin{tabular}{c|c|c|c}
\hline Parameter & Time & Treatment & Interaction \\
\hline Total bacterial count & $23.31^{* * *}$ & $5.77^{* * *}$ & $8.15^{* * *}$ \\
Moulds & $0.15^{\mathrm{ns}}$ & $0.80^{\mathrm{ns}}$ & $1.21^{\mathrm{ns}}$ \\
Actinobacteria & $77.02^{* * *}$ & $3.34^{* *}$ & $10.20^{* * *}$ \\
Copiotrophs & $29.34^{* * *}$ & $2.29^{*}$ & $2.87^{* *}$ \\
Oligotrophs & $97.19^{* * *}$ & $22.05^{* * *}$ & $15.60^{* * *}$ \\
\hline
\end{tabular}

The research showed the influence of individual herbicides on the total bacterial count (Table 4). In comparison with the control variant, the xenobiotic treatment with Stellar 210 SL + Olbras (a.s. dicamba, topramezone + adjuvant), Laudis 44 OD (a.s. tembotrione) and Collage 064 OD (a.s. nicosulfuron, thifensulfuron-methyl) caused an 
increase in the total bacterial count at all the three terms. When Maister Power 42.5 OD (a.s. iodosulfuron-methyl-sodium, foramsulfuron, thiencarbazone-methyl) was applied, the total bacterial count was similar to the count in the control variant during the whole period of the research. When Hector Max $66.5 \mathrm{WG}+$ Trend $0.1 \%$ (a.s. nicosulfuron, rimsulfuron, dicamba + adjuvant) and Arigo $51 \mathrm{WG}+$ Trend $0.1 \%$ (a.s. mesotrione, nicosulfuron, rimsulfuron + adjuvant) were applied, the count of bacteria was greater than in the control variant at the first and third term. However, at the second term the bacterial count was respectively about $60 \%$ and $70 \%$ lower than in the soil which had not been treated with the herbicides.

The research revealed that the herbicides caused considerable fluctuations in the count of oligotrophs. Three days after the application (the first term) of Stellar $210 \mathrm{SL}+$ Olbras (a.s. dicamba, topramezone + adjuvant), Collage 064 OD (a.s. nicosulfuron, thifensulfuron-methyl) and Hector Max 66.5 WG + Trend $0.1 \%$ (a.s. nicosulfuron, rimsulfuron, dicamba + adjuvant) the crop protection products stimulated the growth of oligotrophs, as their count was greater than in the control variant (Table 4). At the second term of analyses, i.e. thirty days after the herbicide treatment, the count of oligotrophs increased in the variants where Stellar 210 SL + Olbras (a.s. dicamba, topramezone + adjuvant), Maister Power 42.5 OD (a.s. iodosulfuron-methyl-sodium, foramsulfuron, thiencarbazone-methyl) and Collage 064 OD (a.s. nicosulfuron, thifensulfuron-methyl) had been applied. Sixty days after the herbicide treatment the count of these microorganisms dropped in all the variants, as compared with the control sample.

Like oligotrophs, the count of copiotrophs fluctuated during the whole period of the research. It depended on the chemical product and the time after the treatment.

Table 4. The effect of herbicides on the number of microorganisms

\begin{tabular}{|c|c|c|c|}
\hline \multirow[b]{2}{*}{ Experimental combination } & \multicolumn{3}{|c|}{ Term of analysis } \\
\hline & $\begin{array}{l}3 \text { days after } \\
\text { herbicides } \\
\text { application }\end{array}$ & $\begin{array}{c}30 \text { days after } \\
\text { herbicides } \\
\text { application }\end{array}$ & $\begin{array}{c}60 \text { days after } \\
\text { herbicides } \\
\text { application }\end{array}$ \\
\hline \multicolumn{4}{|c|}{ 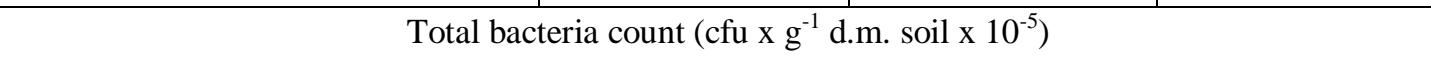 } \\
\hline Control & $2.71 \mathrm{a} \pm 0.98$ & $14.93 \mathrm{c}-\mathrm{h} \pm 5.81$ & $5.81 \mathrm{a}-\mathrm{d} \pm 1.78$ \\
\hline Stellar 210 SL + Olbras & $3.43 \mathrm{ab} \pm 1.09$ & $17.46 \mathrm{f}-\mathrm{h} \pm 4.26$ & $8.10 \mathrm{a}-\mathrm{f} \pm 2.02$ \\
\hline Maister Power 42.5 OD & $3.90 \mathrm{ab} \pm 1.86$ & $18.04 \mathrm{~h} \pm 3.52$ & $5.60 \mathrm{a}-\mathrm{c} \pm 2.79$ \\
\hline Laudis 44 OD & $8.34 \mathrm{a}-\mathrm{g} \pm 2.56$ & $17.38 \mathrm{f}-\mathrm{h} \pm 6.42$ & $12.08 \mathrm{a}-\mathrm{h} \pm 2.80$ \\
\hline Collage 064 OD & $12.44 \mathrm{~b}-\mathrm{h} \pm 2.49$ & $18.01 \mathrm{gh} \pm 6.34$ & $15.27 \mathrm{~d}-\mathrm{h} \pm 4.86$ \\
\hline Hector Max 66.5 WG + Trend $0.1 \%$ & $12.50 \mathrm{~b}-\mathrm{h} \pm 1.76$ & $5.98 \mathrm{a}-\mathrm{d} \pm 2.20$ & $17.97 \mathrm{gh} \pm 3.94$ \\
\hline Arigo $51 \mathrm{WG}+$ Trend $0.1 \%$ & $6.52 \mathrm{a}-\mathrm{e} \pm 2.55$ & $4.92 \mathrm{ab} \pm 2.62$ & 16.08 e-h \pm 2.68 \\
\hline \multicolumn{4}{|c|}{ Actinobacteria $\left(\mathrm{cfu} \mathrm{x} \mathrm{g}{ }^{-1}\right.$ d.m. soil x $\left.10^{4}\right)$} \\
\hline Control & $2.09 \mathrm{a} \pm 1.44$ & $2.41 \mathrm{a} \pm 1.36$ & $13.05 \mathrm{a}-\mathrm{d} \pm 5.54$ \\
\hline Stellar 210 SL + Olbras & $2.78 \mathrm{a} \pm 1.06$ & $5.16 \mathrm{a} \pm 2.03$ & $6.29 \mathrm{ab} \pm 5.23$ \\
\hline Maister Power 42.5 OD & $2.17 \mathrm{a} \pm 2.06$ & $12.14 \mathrm{a}-\mathrm{c} \pm 3.30$ & $3.83 \mathrm{a} \pm 2.83$ \\
\hline Laudis 44 OD & $2.38 \mathrm{a} \pm 1.24$ & $2.06 \mathrm{a} \pm 0.89$ & $6.89 \mathrm{a}-\mathrm{c} \pm 4.75$ \\
\hline Collage 064 OD & $4.89 \mathrm{a} \pm 3.73$ & $3.17 \mathrm{a} \pm 0.64$ & $13.75 \mathrm{~d} \pm 4.55$ \\
\hline Hector Max 66.5 WG + Trend $0.1 \%$ & $1.72 \mathrm{a} \pm 1.46$ & $3.83 \mathrm{a} \pm 1.66$ & $16.18 \mathrm{~d} \pm 4.19$ \\
\hline Arigo $51 \mathrm{WG}+$ Trend $0.1 \%$ & $1.54 \mathrm{a} \pm 1.04$ & $3.51 \mathrm{a} \pm 1.16$ & $11.39 \mathrm{bc} \pm 2.41$ \\
\hline
\end{tabular}




\begin{tabular}{|c|c|c|c|}
\hline \multicolumn{4}{|c|}{ Moulds (cfu x g ${ }^{-1}$ d.m. soil x $10^{4}$ ) } \\
\hline Control & $4.61 \mathrm{a} \pm 1.36$ & $3.39 \mathrm{a} \pm 1.56$ & $2.30 \mathrm{a} \pm 0.20$ \\
\hline Stellar 210 SL + Olbras & $4.46 \mathrm{a} \pm 1.20$ & $6.07 \mathrm{a} \pm 1.38$ & $3.06 \mathrm{a} \pm 0.50$ \\
\hline Maister Power 42.5 OD & $4.08 \mathrm{a} \pm 1.48$ & $4.31 \mathrm{a} \pm 1.18$ & $3.83 \mathrm{a} \pm 0.95$ \\
\hline Laudis $44 \mathrm{OD}$ & $2.47 \mathrm{a} \pm 0.19$ & $3.02 \mathrm{a} \pm 1.33$ & $3.99 \mathrm{a} \pm 0.27$ \\
\hline Collage 064 OD & $2.64 \mathrm{a} \pm 1.08$ & $1.83 \mathrm{a} \pm 0.40$ & $4.47 \mathrm{a} \pm 0.96$ \\
\hline Hector Max 66.5 WG + Trend $0.1 \%$ & $4.11 \mathrm{a} \pm 0.63$ & $1.77 \mathrm{a} \pm 0.09$ & $3.61 \mathrm{a} \pm 0.31$ \\
\hline Arigo $51 \mathrm{WG}+$ Trend $0.1 \%$ & $2.03 \mathrm{a} \pm 0.95$ & $4.85 \mathrm{a} \pm 0.09$ & $1.58 \mathrm{a} \pm 0.60$ \\
\hline \multicolumn{4}{|c|}{ Oligotrophic bacteria (cfu x g ${ }^{-1}$ d.m. soil x $10^{5}$ ) } \\
\hline Control & $26.03 \mathrm{de} \pm 1.10$ & $14.66 \mathrm{a}-\mathrm{d} \pm 5.68$ & $13.24 \mathrm{a}-\mathrm{d} \pm 2.76$ \\
\hline Stellar 210 SL + Olbras & $42.93 \mathrm{f} \pm 5.82$ & 38.06 ef \pm 3.70 & $10.68 \mathrm{ab} \pm 1.41$ \\
\hline Maister Power 42.5 OD & $7.49 \mathrm{ab} \pm 0.96$ & $25.33 \mathrm{a}-\mathrm{c} \pm 4.89$ & $4.13 \mathrm{a} \pm 2.33$ \\
\hline Laudis $44 \mathrm{OD}$ & $22.04 b c \pm 6.70$ & $9.37 \mathrm{ab} \pm 2.43$ & $11.41 \mathrm{a}-\mathrm{d} \pm 2.41$ \\
\hline Collage 064 OD & $57.58 \mathrm{~g} \pm 5.35$ & $16.27 \mathrm{a}-\mathrm{d} \pm 3.5$ & $8.95 \mathrm{ab} \pm 3.64$ \\
\hline Hector Max 66.5 WG + Trend $0.1 \%$ & 37.99 ef \pm 6.10 & $9.01 \mathrm{ab} \pm 3.11$ & $11.13 \mathrm{a}-\mathrm{c} \pm 2.00$ \\
\hline Arigo $51 \mathrm{WG}+$ Trend $0.1 \%$ & $18.07 \mathrm{a}-\mathrm{d} \pm 4.14$ & $5.43 \mathrm{a} \pm 2.57$ & $7.32 \mathrm{a} \pm 1.87$ \\
\hline \multicolumn{4}{|c|}{ Copiotrophic bacteria (cfu x g ${ }^{-1}$ d.m. soil x $10^{5}$ ) } \\
\hline Control & $19.97 \mathrm{~b}-\mathrm{e} \pm 4.34$ & $17.53 \mathrm{a}-\mathrm{e} \pm 6.41$ & $11.45 \mathrm{a}-\mathrm{d} \pm 1.47$ \\
\hline Stellar $210 \mathrm{SL}+$ Olbras & $21.29 \mathrm{~b}-\mathrm{e} \pm 4.98$ & $25.13 \mathrm{a}-\mathrm{d} \pm 7.38$ & $11.02 \mathrm{a}-\mathrm{d} \pm 1.92$ \\
\hline Maister Power 42.5 OD & $12.48 \mathrm{a}-\mathrm{d} \pm 6.22$ & $13.03 \mathrm{de} \pm 3.88$ & $6.89 \mathrm{ab} \pm 5.09$ \\
\hline Laudis $44 \mathrm{OD}$ & $18.84 \mathrm{a}-\mathrm{e} \pm 0.55$ & $24.51 \mathrm{a}-\mathrm{d} \pm 3.40$ & $12.13 \mathrm{a}-\mathrm{d} \pm 2.92$ \\
\hline Collage 064 OD & $30.21 \mathrm{e} \pm 0.55$ & $10.13 \mathrm{a}-\mathrm{d} \pm 5.34$ & $13.61 \mathrm{a}-\mathrm{d} \pm 6.82$ \\
\hline Hector Max 66.5 WG + Trend $0.1 \%$ & $23.92 \mathrm{de} \pm 3.46$ & $20.54 \mathrm{~b}-\mathrm{e} \pm 5.32$ & $7.31 \mathrm{a}-\mathrm{c} \pm 2.47$ \\
\hline Arigo $51 \mathrm{WG}+$ Trend $0.1 \%$ & $23.74 \mathrm{c}-\mathrm{e} \pm 3.84$ & $25.34 \mathrm{de} \pm 5.83$ & $2.79 \mathrm{a} \pm 1.43$ \\
\hline
\end{tabular}

Note: data are represented as means of five replications. Values after means are standard deviations \pm ; mean values \pm standard errors; a, b, c, d, e - homogenous groups according to Tuckey's test; different letters denote statistical differences at level $\alpha=0.05 ; \mathrm{n}=5$

In comparison with the control soil variant, immediately after treatment with the crop protection products and thirty days after the treatment the count of copiotrophic bacteria increased in the variants with Stellar $210 \mathrm{SL}+$ Olbras (a.s. dicamba, topramezone + adjuvant), Hector Max 66.5 WG + Trend $0.1 \%$ (a.s. nicosulfuron, rimsulfuron, dicamba + adjuvant) and Arigo $51 \mathrm{WG}+$ Trend $0.1 \%$ (a.s. mesotrione, nicosulfuron, rimsulfuron + adjuvant). However, sixty days after the treatment there was an inverse dependence - the count of copiotrophic bacteria decreased. When Maister Power 42.5 OD (a.s. iodosulfuron-methyl-sodium, foramsulfuron, thiencarbazone-methyl) was applied, it inhibited the count of copiotrophs at each of the three terms of analyses, as compared with the soil which was not treated with herbicides (Table 4). The count of copiotrophs in the variants where Laudis 44 OD (a.s. tembotrione) and Collage 064 OD (a.s. nicosulfuron, thifensulfuron-methyl) were applied fluctuated continuously during the whole research period.

Actinobacteria were another group of microorganisms under study (Table 4). At the first term of soil sample collection the count of actinobacteria in most of the herbicide variants was similar to the count in the control variant. Only treatment with Collage 064 OD (a.s. nicosulfuron, thifensulfuron-methyl) caused the count of actinobacteria to increase by more than $100 \%$. Thirty days after the herbicide treatment Maister Power 
42.5 OD (a.s. iodosulfuron-methyl-sodium, foramsulfuron, thiencarbazone-methyl) had the most stimulating effect on actinobacteria as their count was almost 5 times greater than in the control variant. At the last term of analyses, i.e. sixty days after the herbicide treatment, only Collage 064 OD (a.s. nicosulfuron, thifensulfuron-methyl) and Hector Max 66.5 WG + Trend $0.1 \%$ (a.s. nicosulfuron, rimsulfuron, dicamba + adjuvant) caused an increase in the count of actinobacteria, whereas the other herbicides resulted in a decrease. The greatest decrease in the count of actinobacteria at the last term of analyses was noted in the Maister Power 42.5 OD variant (a.s. iodosulfuron-methylsodium, foramsulfuron, thiencarbazone-methyl).

Like all groups of microorganisms, moulds also responded to the herbicide treatment with changes in their count in soil (Table 4). At the first term each of the crop protection products decreased the population of these microorganisms. Arigo $51 \mathrm{WG}+$ Trend $0.1 \%$ (a.s. mesotrione, nicosulfuron, rimsulfuron + adjuvant) was the most toxic as it decreased the count of moulds by more than $56 \%$, as compared with the control variant. Thirty days after the herbicide treatment Stellar 210 SL + Olbras (a.s. dicamba, topramezone + adjuvant), Maister Power 42.5 OD (a.s. iodosulfuron-methyl-sodium, foramsulfuron, thiencarbazone-methyl) and Arigo $51 \mathrm{WG}+$ Trend $0.1 \%$ (a.s. mesotrione, nicosulfuron, rimsulfuron + adjuvant) caused an increase in the count of moulds. Sixty days after the herbicide treatment only the Arigo $51 \mathrm{WG}+$ Trend $0.1 \%$ variant (a.s. mesotrione, nicosulfuron, rimsulfuron + adjuvant) had negative effect on the population of these microorganisms.

\section{Soil biochemical activity}

The herbicides had significant influence on the enzymatic activity of alkaline phosphatase, catalase and BIF. They did not have significant influence on the activity of dehydrogenase or acid phosphatase (Table 5).

Table 5. F test statistics and significance levels of two-way analysis of variance for the enzymes activity associated with herbicides and terms research fixed factors $(* * * p=0.001$. $* * p=0.01 . * p=0.05 . n s-$ not statistically significant)

\begin{tabular}{c|c|c|c}
\hline Parameter & Time & Treatment & Interaction \\
\hline Dehydrogenase & $0.03^{\text {ns }}$ & $0.82^{\text {ns }}$ & $1.89^{*}$ \\
Alkaline phosphatase & $495.52^{* * * *}$ & $87.40^{* * *}$ & $82.66^{* * *}$ \\
Acid phosphatase & $32.59^{* * *}$ & $0.65^{\text {ns }}$ & $0.62^{\text {ns }}$ \\
Catalase & $19051.80^{* * *}$ & $4312.67^{* * *}$ & $2691.16^{* * *}$ \\
BIF & $39.00^{* * * *}$ & $8.77^{* * *}$ & $9.05^{* * *}$ \\
\hline
\end{tabular}

As can be seen in Figure 2 the greatest fluctuations in the dehydrogenase activity were observed thirty days after the herbicide treatment. Maister Power 42.5 OD (a.s. iodosulfuron-methyl-sodium, foramsulfuron, thiencarbazone-methyl), Laudis 44 OD (a.s. tembotrione) and Arigo $51 \mathrm{WG}+$ Trend $0.1 \%$ (a.s. mesotrione, nicosulfuron, rimsulfuron + adjuvant) caused increased activity of these enzymes. The last variant increased the dehydrogenase activity nearly 5 times. Sixty days after the treatment the activity of these enzymes in all the variants with herbicides dropped below the value noted in the control variant. 


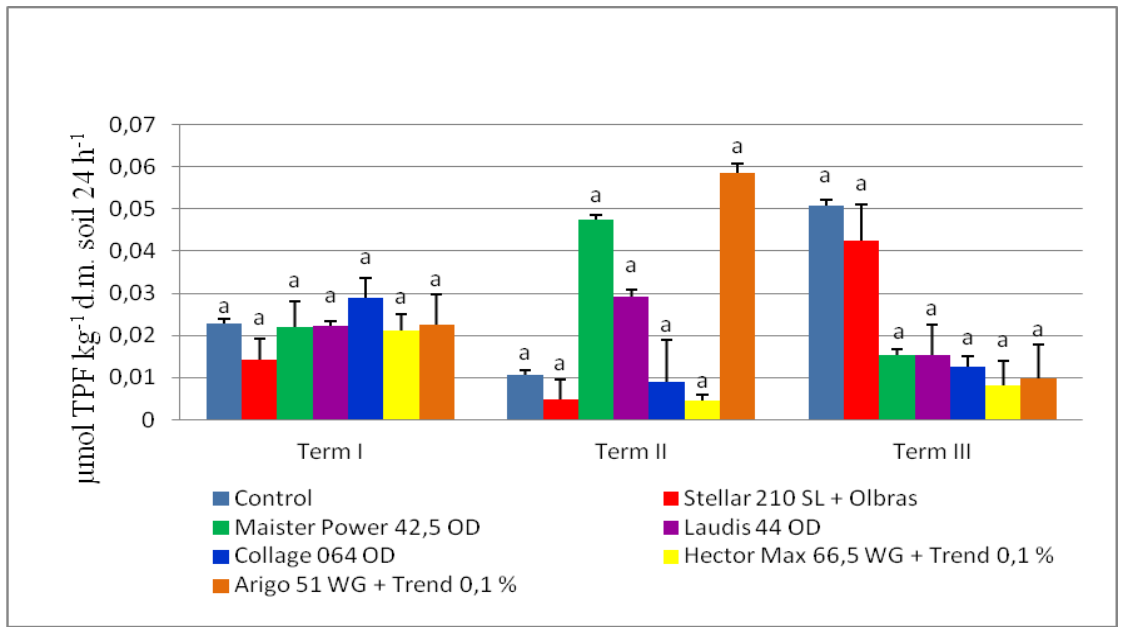

Figure 2. The effect of herbicides on dehydrogenase activity. Note: data are represented as means of five replications. Vertical bars are standard deviation \pm ; mean values \pm standard errors; $a, b, c, d, e$-homogenous groups according to Tuckey's test; different letters denote statistical differences at level $\alpha=0.05 ; n=5$

The alkaline phosphatase activity in the samples collected three days after the herbicide treatment was similar in all the variants of the experiment (Fig. 3). At the second term of analyses the activity of these enzymes was lower in the variants treated with herbicides than in the control soil sample. Sixty days after the treatment with xenobiotics the alkaline phosphatase activity increased only in the Stellar 210 SL + Olbras (a.s. dicamba, topramezone + adjuvant) and Maister Power 42.5 OD variants (a.s. iodosulfuron-methyl-sodium, foramsulfuron, thiencarbazone-methyl). Laudis 44 OD (a.s. tembotrione) was the most toxic herbicide to alkaline phosphatase at that term of analyses. In comparison with the control variant the activity of this enzyme was reduced by more than $80 \%$.

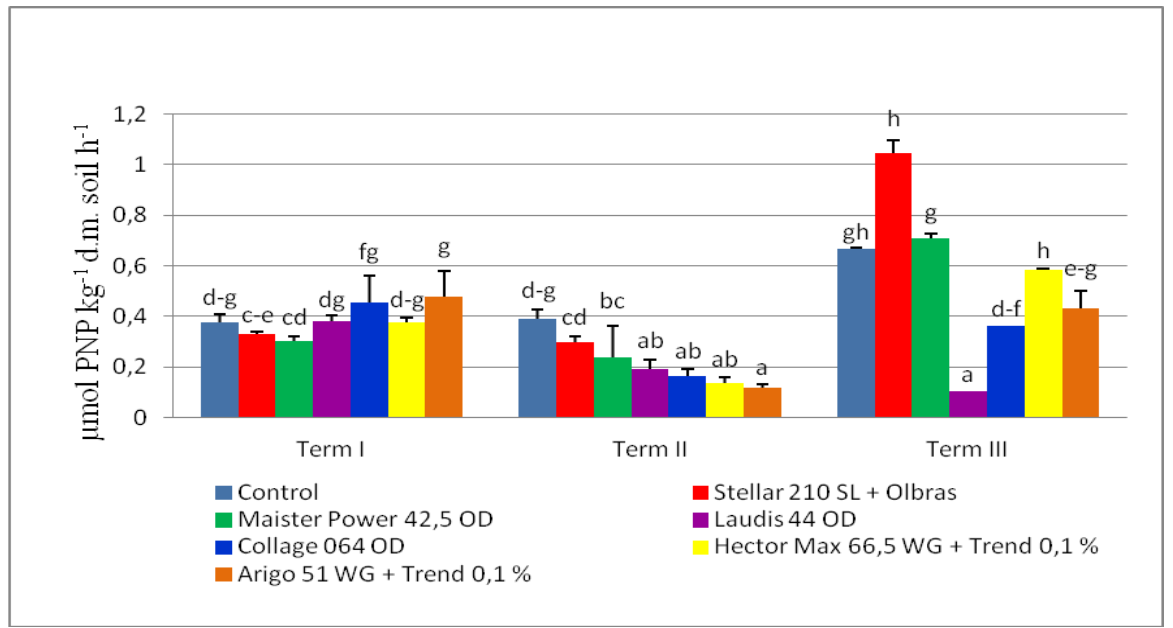

Figure 3. The effect of herbicides on alkaline phosphatase activity. Note: data are represented as means of five replications. Vertical bars are standard deviation \pm ; mean values \pm standard errors; $a, b, c, d, e$-homogenous groups according to Tuckey's test; different letters denote statistical differences at level $\alpha=0.05 ; n=5$ 
The results in Figure 4 show that only at the second term of analyses all the herbicides caused an increase in the acid phosphatase activity, as compared with the control variant. The highest acid phosphatase activity was observed when Arigo 51 WG + Trend $0.1 \%$ (a.s. mesotrione, nicosulfuron, rimsulfuron + adjuvant) was applied. At the other terms there were slight fluctuations in the enzyme activity, as compared with the control variant.

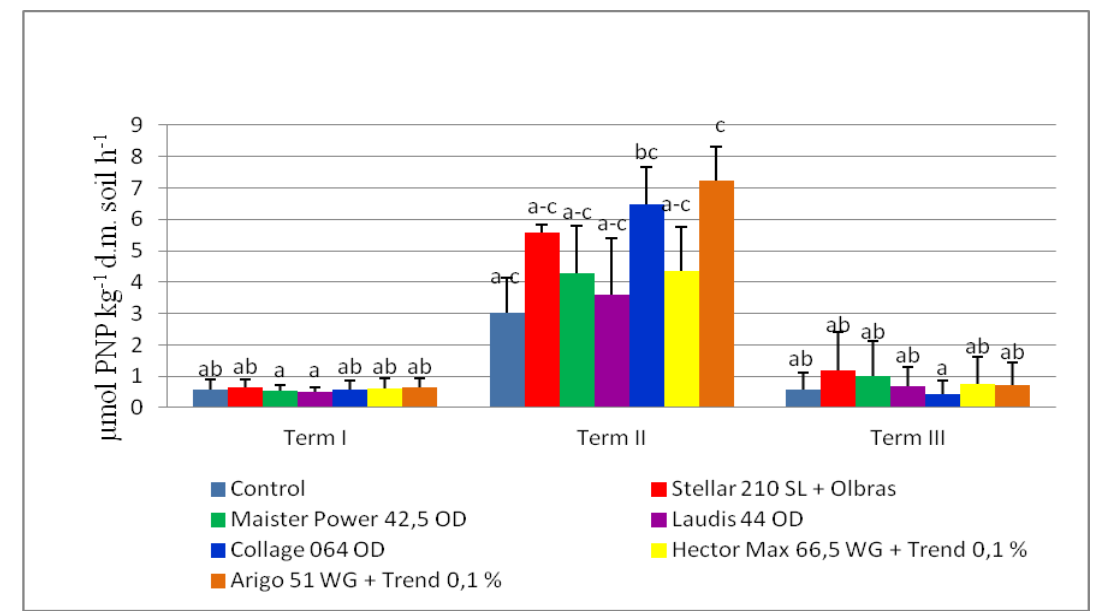

Figure 4. The effect of herbicides on acid phosphatase activity. Note: data are represented as means of five replications. Vertical bars are standard deviation \pm ; mean values \pm standard errors; $a, b, c, d, e$-homogenous groups according to Tuckey's test; different letters denote statistical differences at level $\alpha=0.05 ; n=5$

The catalase activity was also measured to assess the microbial state of soil. The data in Figure 5 show that only at the first term of analyses the activity of this enzyme was stable and remained at a high level. There were no significant changes in comparison with the control sample. After thirty days of the experiment most of the herbicides reduced the catalase activity, as compared with the control sample. Nevertheless, the catalase activity in the variants with Arigo $51 \mathrm{WG}+$ Trend $0.1 \%$ (a.s. mesotrione, nicosulfuron, rimsulfuron + adjuvant) and Collage 064 OD (a.s. nicosulfuron, thifensulfuron-methyl) increased 9 and 2 times, respectively. At the last term of analyses, i.e. sixty days after the treatment with xenobiotics, the catalase activity in the variants with Arigo $51 \mathrm{WG}+$ Trend $0.1 \%$ (a.s. mesotrione, nicosulfuron, rimsulfuron + adjuvant) and Collage 064 OD (a.s. nicosulfuron, thifensulfuron-methyl) was higher than in the control variant.

The research also enabled measurement of the biological index of fertility (BIF) in all the variants (Fig. 6). The index value was based on the dehydrogenase and catalase activity. The highest values of the index were noted thirty days after the herbicide treatment $\left(2^{\text {nd }}\right.$ term). The treatment with Arigo $51 \mathrm{WG}+$ Trend $0.1 \%$ (a.s. mesotrione, nicosulfuron, rimsulfuron + adjuvant), Maister Power 42.5 OD (a.s. iodosulfuronmethyl-sodium, foramsulfuron, thiencarbazone-methyl) and Laudis 44 OD (a.s. tembotrione) resulted in higher values of the index. At the last term the results noted in the variants treated with the herbicides were lower than in the control variant.

The sensitivity value (RS) in Table 6 shows that the soil enzymes differed in their response to pollution with the herbicides. This index of resistance is bounded by -1 and +1 , where the value of +1 shows that disturbance had no effect (maximum resistance), 
whereas lower values indicate stronger effects (lower resistance). The lowest RS value for dehydrogenase in the soil was noted immediately after the treatment with Stellar 210 SL + Olbras (a.s. dicamba, topramezone + adjuvant) and Arigo $51 \mathrm{WG}+$ Trend $0.1 \%$ (a.s. mesotrione, nicosulfuron, rimsulfuron + adjuvant). At the consecutive terms of analyses, i.e. thirty and sixty days after the herbicide treatment, the RS value for dehydrogenase was close to ' 1 ' and it ranged from 0.785 to 0.983 and from 0.887 to 0.904 , respectively. The sensitivity of alkaline phosphatase to the herbicides was different during the experiment. The lowest RS value was noted thirty days after the herbicide treatment. It amounted to -0.029 after the treatment with Hector Max 66.5 WG + Trend $0.1 \%$ (a.s. nicosulfuron, rimsulfuron, dicamba + adjuvant). Sixty days after the herbicide treatment the highest sensitivity of the enzyme was observed in the Laudis 44 OD (a.s. tembotrione) and Collage 064 OD (a.s. nicosulfuron, thifensulfuron-methyl) variants (Table 6).

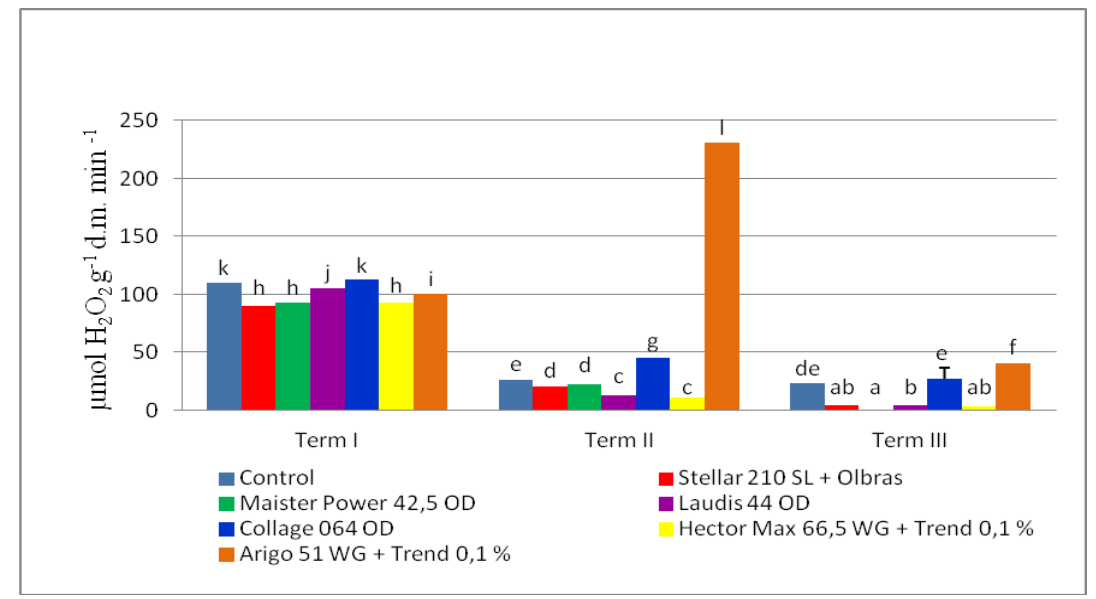

Figure 5. The effect of herbicides on catalase activity. Note: data are represented as means of five replications. Vertical bars are standard deviation \pm ; mean values \pm standard errors; $a, b, c$, $d, e$-homogenous groups according to Tuckey's test; different letters denote statistical differences at level $\alpha=0.05 ; n=5$

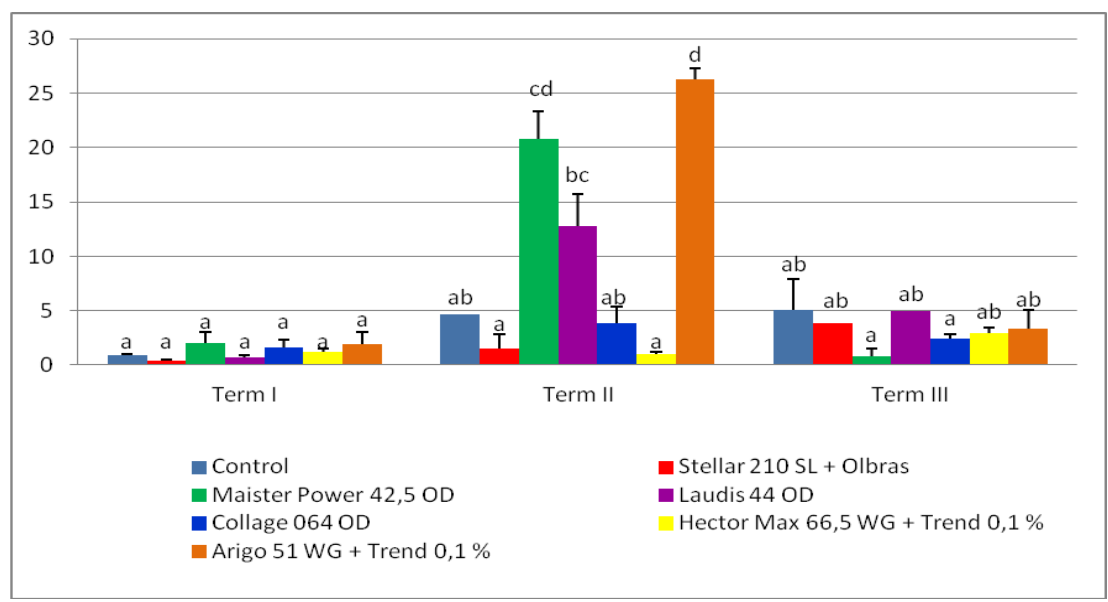

Figure 6. The effect of herbicides on BIF. Note: data are represented as means of five replications. Vertical bars are standard deviation \pm ; means values \pm standard errors; $a, b, c, d$, $e$-homogenous groups according to Tuckey's test; different letters denote statistical differences at level $\alpha=0.05 ; n=5$ 
Table 6. Resistance of soil enzymes to contamination with herbicides. (PAC - acid phosphatase activity; PAL - alkaline phosphatase activity; DHA - dehydrogenase activity)

\begin{tabular}{|c|c|c|c|}
\hline \multirow[b]{2}{*}{ Experimental variant } & \multicolumn{3}{|c|}{ Term of analysis } \\
\hline & $\begin{array}{l}3 \text { days after } \\
\text { herbicides } \\
\text { application }\end{array}$ & $\begin{array}{l}\text { 30 days after } \\
\text { herbicides } \\
\text { application }\end{array}$ & $\begin{array}{l}60 \text { days after } \\
\text { herbicides } \\
\text { application }\end{array}$ \\
\hline \multicolumn{4}{|c|}{ RS index of DHA } \\
\hline $\begin{array}{l}\text { Stellar } 210 \mathrm{SL}+\text { Olbras (a.s. dicamba. } \\
\text { topramezon + adjuvant) }\end{array}$ & -0.153 & 0.958 & 0.876 \\
\hline $\begin{array}{l}\text { Maister Power } 42.5 \text { OD (a.s. iodosulfuron- } \\
\text { methyl-sodium, foramsulfuron, methyl } \\
\text { thiencarbazone }\end{array}$ & 0.365 & 0.833 & 0.889 \\
\hline Laudis 44 OD (a.s. tembotrion) & 0.769 & 0.887 & 0.904 \\
\hline $\begin{array}{l}\text { Collage } 064 \text { OD (a.s. nicosulfuron, } \\
\text { thifensulfuron-methyl) }\end{array}$ & 0.403 & 0.983 & 0.903 \\
\hline $\begin{array}{c}\text { Hector Max } 66.5 \text { WG + Trend } 0.1 \% \text { (a.s } \\
\text { nicosulfuron, rimsulfuron, dicamba }+ \\
\text { adjuvant) }\end{array}$ & 0.530 & 0.947 & 0.895 \\
\hline $\begin{array}{c}\text { Arigo } 51 \mathrm{WG}+\text { Trend } 0.1 \% \text { (a.s. mesotrione, } \\
\text { nicosulfuron, rimsulfuron + adjuvant) }\end{array}$ & 0.288 & 0.785 & 0.887 \\
\hline \multicolumn{4}{|c|}{ RS index of PAC } \\
\hline $\begin{array}{l}\text { Stellar } 210 \text { SL + Olbras (a.s. dicamba, } \\
\text { topramezon + adjuvant) }\end{array}$ & 0.363 & 0.554 & 0.464 \\
\hline $\begin{array}{l}\text { Maister Power } 42.5 \text { OD (a.s. iodosulfuron- } \\
\text { methyl-sodium, foramsulfuron, methyl } \\
\text { thiencarbazone }\end{array}$ & 0.692 & 0.815 & 0.434 \\
\hline Laudis 44 OD (a.s. tembotrion) & 0.799 & 0.784 & 0.340 \\
\hline $\begin{array}{l}\text { Collage } 064 \text { OD (a.s. nicosulfuron, } \\
\text { thifensulfuron-methyl) }\end{array}$ & 0.657 & 0.450 & 0.346 \\
\hline $\begin{array}{c}\text { Hector Max } 66.5 \text { WG + Trend } 0.1 \% \text { (a.s } \\
\text { nicosulfuron, rimsulfuron, dicamba }+ \\
\text { adjuvant) }\end{array}$ & 0.785 & -0.029 & 0.500 \\
\hline $\begin{array}{l}\text { Arigo } 51 \mathrm{WG}+\text { Trend } 0.1 \% \text { (a.s. mesotrione, } \\
\text { nicosulfuron, rimsulfuron + adjuvant) }\end{array}$ & 0.699 & 0.231 & 0.534 \\
\hline \multicolumn{4}{|c|}{ RS index of PAL } \\
\hline $\begin{array}{l}\text { Stellar } 210 \text { SL + Olbras (a.s. dicamba, } \\
\text { topramezon + adjuvant) }\end{array}$ & 0.767 & 0.629 & 0.279 \\
\hline $\begin{array}{l}\text { Maister Power } 42.5 \text { OD (a.s. iodosulfuron- } \\
\text { methyl-sodium, foramsulfuron, methyl } \\
\text { thiencarbazone }\end{array}$ & 0.895 & 0.553 & 0.329 \\
\hline Laudis 44 OD (a.s. tembotrion) & 0.740 & 0.703 & 0.0483 \\
\hline $\begin{array}{l}\text { Collage } 064 \text { OD (a.s. nicosulfuron, } \\
\text { thifensulfuron-methyl) }\end{array}$ & 0.763 & 0.802 & 0.437 \\
\hline $\begin{array}{c}\text { Hector Max } 66.5 \text { WG + Trend } 0.1 \% \text { (a.s } \\
\text { nicosulfuron, rimsulfuron, dicamba }+ \\
\text { adjuvant) }\end{array}$ & 0.741 & 0.859 & 0.502 \\
\hline $\begin{array}{c}\text { Arigo } 51 \mathrm{WG}+\text { Trend } 0.1 \% \text { (a.s. mesotrione, } \\
\text { nicosulfuron, rimsulfuron + adjuvant) }\end{array}$ & 0.693 & 0.910 & 0.643 \\
\hline
\end{tabular}


The results concerning the influence of the herbicides on the soil bioactivity were illustrated by means of principal component analysis (PCA) (Fig. 7). The analysis showed highly significant dependences occurring in the soil environment under maize plantation after the herbicide treatment. There was a high positive correlation between the biological parameters such as the total bacterial count and the count of actinobacteria and the alkaline phosphatase activity sixty days after the herbicide treatment. On the other hand, the dehydrogenase activity, the biological index of fertility (BIF) and the count of moulds were negatively correlated with the effect of the crop protection products at all the terms of the analyses.

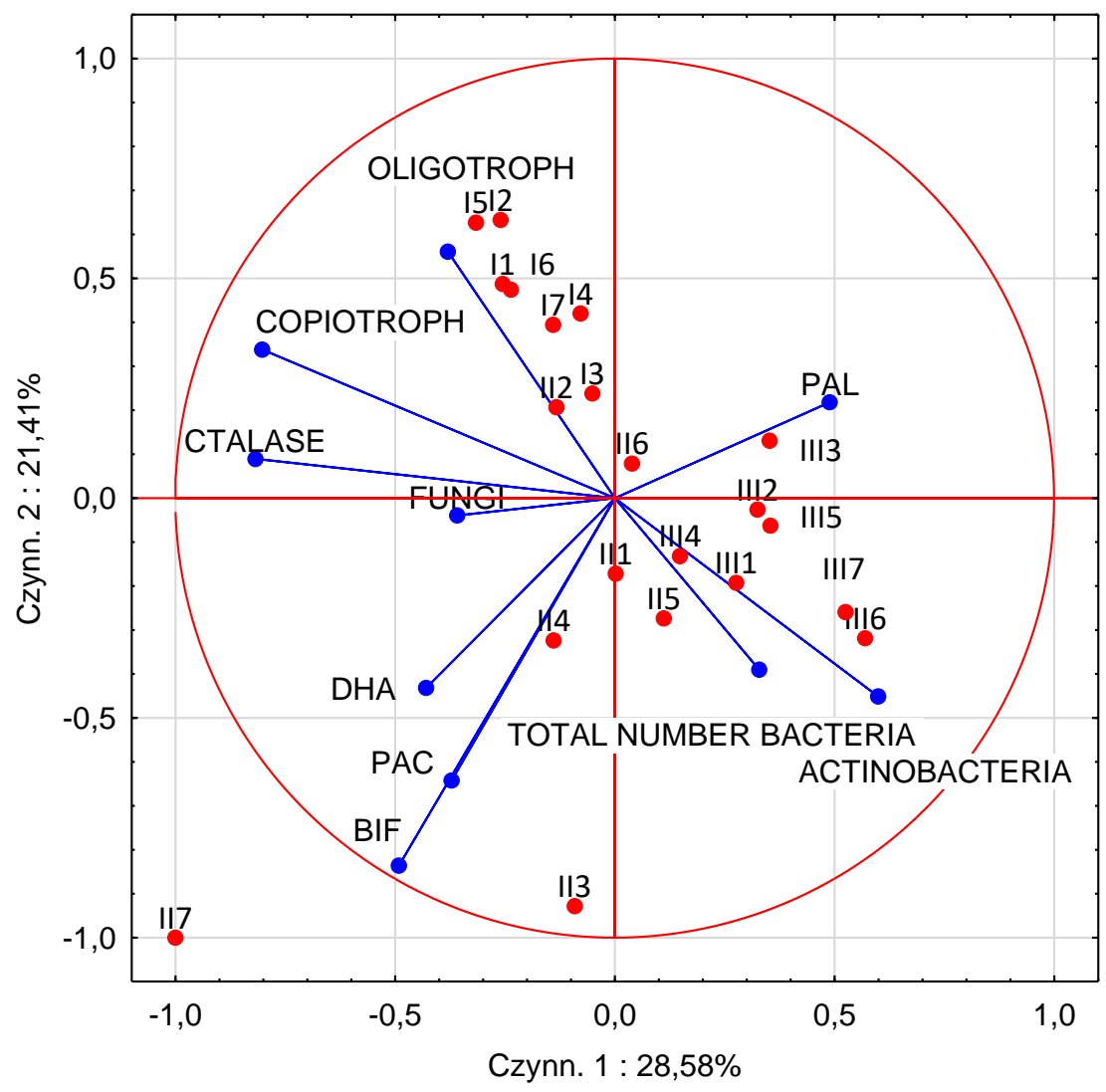

Figure 7. The dependence between the population of microorganisms and soil enzymatic activity for all variants with herbicides at the terms of analyses; I, 3 days after herbicides application; II, 30 days after herbicide treatment; III, 60 days after herbicide treatment; 1, control; 2, Stellar 210 SL + Olbras; 3, Maister Power 42.5 OD; 4, Laudis 44 OD; 5 Collage 064 OD; 6 Hector Max 66.5 WG + Trend $0.1 \%$; 7 Arigo 51 WG + Trend 0.1\%; PAC - acid phosphatase; PAL-alkaline phosphatase; DHA - dehydrogenase; $R S$ - soil resistance

\section{Discussion}

The count of microorganisms and the enzymatic activity are important biological indicators of soil. The dynamics of changes in the count of microorganisms may be caused by cultivation, fertilisation and chemical crop protection. Herbicides may influence the count of soil bacteria, which participate in the processes responsible for soil fertility. 
The results of our study show that the crop protection products used during maize growing had diversified influence on the groups of soil microorganisms under analysis, which depended on the products and the term of analyses. Apart from that, there was high diversification in the populations of different microorganisms colonising the soil environment after the application of the chemical crop protection products. The research results showed that the products significantly disturbed the microbial balance, causing changes in the count of oligotrophic and copiotrophic bacteria, actinobacteria, moulds and the total bacterial count.

Hector Max 66.5 WG + Trend and Arigo 51 WG + Trend significantly reduced the total bacterial count thirty days after the treatment. The same herbicides significantly reduced the population of oligotrophs thirty and sixty days after the treatment, whereas Maister Power 42.5 OD had significant negative influence on the development of actinobacteria also at the last term of analyses.

Sixty days after the herbicide treatment the count of actinobacteria and oligotrophs may have been reduced because of the high toxicity of metabolites formed in consequence of the decomposition of the active substances in the herbicides. When pesticides are applied, they undergo various processes in the environment, such as: transformation, degradation, sorption-desorption, volatilisation, uptake by plants, runoff to surface water and transport to groundwater (Chowdhury et al., 2008). Transformation and degradation are two of the major processes regulating the state of the soil environment. Pesticides are transformed into secondary metabolites or they are completely mineralised (Singh et al., 2006). Although abiotic degradation plays a significant role in many cases, the biodegradation of pesticides by microorganisms is usually the most important and predominant process (Karpouzas and Walker, 2000; Chen et al., 2012a, b; Cycoń et al., 2014; Silva et al., 2015). The negative influence of crop protection products on the proliferation of microorganisms was also observed by Sebiamo et al. (2011), who studied atrazine, primextra, paraquat and glyphosate. Niewiadomska et al. (2018) made similar observations.

The results of our study concerning the influence of the active substance in herbicides show that in some cases the count of the groups of microorganisms under study increased (the total bacterial count, the count of copiotrophs), especially immediately after the herbicide treatment, i.e. at the first term of analyses. There are publications (Fečko et al., 2010) which confirm this reaction of the soil microflora and stress the fact that some species of microorganisms use herbicides as a source of carbon and nutrients. Due to the fact that crop protection products have been used in agriculture for decades, microorganisms have adapted to the polluted environment. They have developed natural mechanisms of biodegradation of toxic substances. The capacity of some microorganisms to biodegrade pesticides partly reduces the toxic substances which might affect the yield. It also improves the biological properties of soil. Many studies proved that strains such as Pseudomonas (Fernandes et al., 2014), Acinetobacter (Singh et al., 2004), Rhodococcus (Batra et al., 2009; Fazlurrahman et al., 2009), Arthrobacter (El Sebaï et al., 2011), Bacillus (Wang et al., 2014), Variovorax itp. (Zhang et al., 2012) were capable of total degradation of atrazine (Zhang et al., 2012) and glyphosate. However, in most cases the effectiveness of biodegradation of herbicides by bacteria is significantly correlated with the soil $\mathrm{pH}$, temperature and availability of building elements such as carbon and nitrogen.

The soil enzymes which participate in the biodegradation of natural and anthropogenic compounds are often used as indicators of changes in the soil 
environment caused by the use of crop protection products, including herbicides (Wang et al., 2009; Baćmaga et al., 2012).

The study showed that the enzymes under analysis were sensitive to the herbicides applied in the experiment. Sixty days after the herbicide treatment all the xenobiotics exhibited strongly negative influence on the dehydrogenase activity. The negative influence was also observed thirty days after the treatment with Stellar 210SL + Olbras and Hector Max 66.5 WG + Trend 0.1\%. There were similar observations made by Cycon et al. (2010, 2013), who studied the influence of napropamide and linuron in herbicides, and by Baćmaga et al. (2014), who researched the influence of metazachlor on the dehydrogenase activity.

Our study also showed that alkaline phosphatase exhibited high sensitivity. The activity of this enzyme became significantly reduced thirty days after the soil treatment with all of the herbicides used in the experiment. This phenomenon may have been caused by the low content of organic matter in the soil and by the inhibitory effect of herbicides on local moulds, which are known to produce alkaline phosphatase in soil (Cycon et al., 2013). On the other hand, at the same term of analyses the acid phosphatase activity in the soil variants treated with the herbicides was higher than in the control variant.

Pesticides and their metabolites may also influence physiological processes in microorganisms such as cell lysis and changes in the cell membrane, thus modifying the activity of soil enzymes (Hussain et al., 2009; Romero et al., 2010).

The soil ecosystem is regarded as stable if it can resist stress factors and regain balance shortly (Griffiths and Philippot, 2013; Orwin and Wardle, 2004). Soil stability is usually assessed on the basis of resistance (RS) and resilience (RL). In our study the RS value was calculated by estimating the resistance of soil to contamination with the herbicides and adjuvants (Table 6).

The RS values calculated in our study show that immediately after the herbicide treatment alkaline phosphatase was the least sensitive enzyme, whereas dehydrogenase was the most sensitive. However, alkaline phosphatase exhibited the highest sensitivity thirty days after the treatment. The herbicides caused greater disturbance to the phosphatase activity than to the dehydrogenase activity. Griffith and Philippot (2013) stress the fact that when the soil ecosystem is exposed to long-lasting stress factors, it becomes more stable due to the development of defence mechanisms responsible for its biostability.

\section{Conclusion}

Tested post-emergence herbicides applied to maize caused a statistically significant biological imbalance in the soil, reducing the actinobacteria as well as the number of moulds at the beginning of vegetation, three days after the treatment. The research revealed very high sensitivity of dehydrogenases and alkaline phosphatase to the soil contamination caused by the application of herbicides. The field doses of the xenobiotics used in the research significantly reduced the dehydrogenase activity in sixty days after the herbicide treatment. The dehydrogenase activity values were strictly correlated with BIF and PAC. 


\section{REFERENCES}

[1] Arias-Estévez, M., López-Periago, E., Martínez-Carballo, E., Simal-Gándara, J., Mejuto, J. C., García-Río, L. (2008): The mobility and degradation of pesticides in soils and the pollution of groundwater resources. - Agriculture, Ecosystems \& Environment 123(4): 247-260.

[2] Baćmaga, M., Kucharski, J., Wyszkowska, J. (2007a): Influence of plant protection products on the microbiological activity of soil. - Journal of Elementology 12(3): 225239 (in Polish).

[3] Baćmaga, M., Kucharski, J., Wyszkowska, J. (2007b): Impact of crop protection chemicals on plants and animals. - Journal of Elementology 12(2): 135-148.

[4] Baćmaga, M., Boros, E., Kucharski, J., Wyszkowska, J. (2012): Enzymatic activity in soil contaminated with the Aurora $40 \mathrm{WG}$ herbicide. - Environment Protection Engineering 38(1): 91-102.

[5] Baćmaga, M., Kucharski, J., Wyszkowska, J., Tomkiel, M. (2013): Biological properties of soil contaminated with the Aurora 40 WG herbicide. - Polish Journal of Natural Sciences 28(2): 163-174.

[6] Baćmaga, M., Kucharski, J., Wyszkowska, J., Borowik, A., Tomkiel, M. (2014): Responses of microorganisms and enzymes to soil contamination with metazachlor. Environmental Earth Sciences 72(7): 2251-2262.

[7] Batra, M., Pandey, J., Suri, C. R., Jain, R. K. (2009): Isolation and characterization of an atrazine degrading Rhodococcus sp. strain MBP1 from contaminated soil. - Letters in Applied Microbiology 49(6): 721-729.

[8] Chowdhury, A., Pradhan, S., Saha, M., Sanyal, N. (2008): Impact of pesticides on soil microbiological parameters and possible bioremediation strategies. - Indian Journal of Microbiology 48(1): 114-127.

[9] Chen, L., Song, F., Liu, Z., Zheng, Z., Xing, J., Liu, S. (2012a): Multi-residue method for fast determination of pesticide residues in plants used in traditional Chinese medicine by ultra-high-performance liquid chromatography coupled to tandem mass spectrometry. Journal of Chromatography A 1225: 132-140.

[10] Chen, S., Hu, W., Xiao, Y., Deng, Y., Jia, J., Hu, M. (2012b): Degradation of 3phenoxybenzoic acid by a Bacillus sp. - PLoS One 7(11): e50456.

[11] Cycoń, M., Piotrowska-Seget, Z., Kozdrój, J. (2010): Linuron effects on microbiological characteristics of sandy soils as determined in a pot study. - Annals of Microbiology 60(3): 439-449.

[12] Cycoń, M., Wójcik, M., Borymski, S., Piotrowska-Seget, Z. (2013): Short-term effects of the herbicide napropamide on the activity and structure of the soil microbial community assessed by the multi-approach analysis. - Applied Soil Ecology 66: 8-18.

[13] Cycoń, M., Zmijowska, A., Piotrowska-Seget, Z. (2014): Enhancement of deltamethrin degradation by soil bioaugmentation with two different strains of Serratia marcescens. International Journal of Environmental Science and Technology 11(5): 1305-1316.

[14] El Sebaï, T., Devers-Lamrani, M., Changey, F., Rouard, N., Martin-Laurent, F. (2011): Evidence of atrazine mineralization in a soil from the Nile Delta: isolation of Arthrobacter sp. TES6, an atrazine-degrading strain. - International Biodeterioration \& Biodegradation 65(8): 1249-1255.

[15] Fazlurrahman, Batra, M., Pandey, J., Suri, C. R., Jain, R. K. (2009): Isolation and characterization of an atrazine-degrading Rhodococcus sp. strain MB-P1 from contaminated soil. - Letters in Applied Microbiology 49(6): 721-729.

[16] Feĉko, P., Pertile, E., Lyckova, B., Vojtkova, H., Janakova, I., Tora, M. (2010): Biodegradation of hazardous pollutants. - Mineral Engineering 11: 41-48 (in Polish).

[17] Fernandes, A. F. T., da Silva, M. B. P., Martins, V. V., Miranda, C. E. S., Stehling, E. G. (2014): Isolation and characterization of a Pseudomonas aeruginosa from a virgin 
Brazilian Amazon region with potential to degrade atrazine. - Environmental Science and Pollution Research 21(24): 13974-13978.

[18] Griffiths, B. S., Philippot, L. (2013): Insights into the resistance and resilience of the soil microbial community. - FEMS Microbiology Reviews 37(2): 112-129.

[19] Hussain, S., Siddique, T., Saleem, M., Arshad, M., Khalid, A. (2009): Impact of pesticides on soil microbial diversity, enzymes, and biochemical reactions. - Advances in Agronomy 102: 159-200.

[20] IUSS Working Group WRB (2007): World Reference Base for Soil Resources 2006, First Update 2007. - World Soil Resources Reports No.103. FAO, Rome.

[21] Johnson, J. L., Temple, K. L. (1964): Some Variables Affecting the Measurement of "Catalase Activity" in Soil 1. - Soil Science Society of America Journal 28(2): 207-209.

[22] Karpouzas, D. G., Walker, A. (2000): Factors influencing the ability of Pseudomonas putida epI to degrade ethoprophos in soil. - Soil Biology and Biochemistry 32(11-12): 1753-1762.

[23] Martin, J. P. (1950): Use of acid, rose bengal, and streptomycin in the plate method for estimating soil fungi. - Soil Science 69(3): 215-232.

[24] Niewiadomska, A., Skrzypczak, G., Sobiech, Ł., Wolna, Maruwka, A., Borowiak, K., Budka, A. (2018): The effect of diflufenican and its mixture with S-metolachlor or metribuzin on the nitrogenase and microbial activity of soil under yellow lupine (Lupinus luteus L.) - Tarim Bilim. Derg. 24(1): 130-142.

[25] Ohta, H., Hattori, T. (1980): Bacteria sensitive to nutrient broth medium in terrestrial environments. - Soil Science and Plant Nutrition 26(1): 99-107.

[26] Orwin, K. H., Wardle, D. A. (2004): New indices for quantifying the resistance and resilience of soil biota to exogenous disturbances. - Soil Biology and Biochemistry 36(11): 1907-1912.

[27] Romero, E., Fernández-Bayo, J., Díaz, J. M. C., Nogales, R. (2010): Enzyme activities and diuron persistence in soil amended with vermicompost derived from spent grape marc and treated with urea. - Applied Soil Ecology 44(3): 198-204.

[28] Saviozzi, A., Cardelli, R., Levi-Minzi, R., Riffaldi, R. (2004): Evolution of biochemical parameters during composting of urban wastes. - Compost Science \& Utilization 12(2): 153-160.

[29] Sebiomo, A., Ogundero, W. V., Bankloe, S. A. (2011): Effect of four herbicides on microbial population, soil organic matter and dehydrogenase activity. - African Journal of Biotechnology 10: 770-778.

[30] Silva, V. P., Moreira-Santos, M., Mateus, C., Teixeira, T., Ribeiro, R., Viegas, C. A. (2015): Evaluation of Arthrobacter aurescens strain TC1 as bioaugmentation bacterium in soils contaminated with the herbicidal substance terbuthylazine. - PloS One 10(12): e0144978.

[31] Singh, B. K., Walker, A. (2006): Microbial degradation of organophosphorus compounds. - FEMS Microbiology Reviews 30(3): 428-471.

[32] Singh, P., Ghoshal, N. (2010): Variation in total biological productivity and soil microbial biomass in rainfed agroecosystems: Impact of application of herbicide and soil amendments. - Agriculture, Ecosystems and Environment 137(3-4): 241-250.

[33] Singh, P., Suri, C. R., Cameotra, S. S. (2004): Isolation of a member of Acinetobacter species involved in atrazine degradation. - Biochemical and Biophysical Research Communications 317(3): 697-702.

[34] Skowera, B., Puła, J. (2004): Pluviometric extreme conditions in spring season in the years 1971-2000. - Acta Agrophysica 3(1): 171-177 (in Polish).

[35] Tabatabai, M. A., Bremner, J. M. (1969): Use of p-nitrophenyl phosphate for assay of soil phosphatase activity. - Soil Biology and Biochemistry 1(4): 301-307.

[36] Thalmann, A. (1968): Zur Methodik der Bestimmung der Dehydrogenase aktivität im Boden mittels triphenytetrazoliumchlorid (TTC). - Landwirtsch Forsch 21: 249-258. 
[37] Van Reeuwijk, L. P. (2002): Procedures for Soil Analysis. $6^{\text {th }}$ ed. - ISRIC, Wageningen Netherlands.

[38] Walker, A., Jurado-Exposito, M., Bending, G. D., Smith, V. J. R. (2001): Spatial variability in the degradation rate of isoproturon in soil. - Environmental Pollution 111(3): 407-415.

[39] Wang, J., Zhu, L., Wang, Q., Wang, J., Xie, H. (2014): Isolation and characterization of atrazine mineralizing Bacillus subtilis strain HB-6. - PloS One 9(9): e107270.

[40] Wang, Q. Y., Zhou, D. M., Cang, L. (2009): Microbial and enzyme properties of apple orchard soil as affected by long-term application of copper fungicide. - Soil Biology and Biochemistry 41(7): 1504-1509.

[41] Zhang, Y., Cao, B., Jiang, Z., Dong, X., Hu, M., Wang, Z. (2012): Metabolic ability and individual characteristics of an atrazine-degrading consortium DNC5. - Journal of hazardous materials 237: 376-381. 